\title{
Pengaruh Motivasi, Minat Dan Kecerdasan Emosional Terhadap Prestasi Belajar Mahasiswa Semester VI di Akademi Keperawatan Dharma Husada
}

\author{
Hengky Irawan. \\ Akper Dharma Husada Kediri
}

Introduction : Learn to represent very basal element in management each, every education ladder and type. Efficacy of school activity can be seen from attainment of achievement learn reachedly. The aim of this research is to identify the influence between motivation, interest, and emotional intellegence with achievement learn semester student of VI Nursing Academy Of Dharma Husada Kediri. Desain Research is quantitative with cross sectional approach. The study was held on December, 2012 at Nursing Academy Of Dharma Husada Kediri. Variables in this study were Motivation, Interest and Emotional Intellegence as independent variables, and the Achievement him Learnas dependent variable. Population in this research was all VI semester student, andsample size was 82 persons. Sampling technique used was total sampling. Data was being collected by questionnaire and index to cumulative achievement. Data Analyzed by using double Linear regression test. Result of of study was the influence of motivation, interest and emotional intellegence to achievement learn with coefficient value of regresi 0.02 and 0.01 ( $\mathrm{t}=5.987$ and 4.334 , interest do not have an effect on by signifikan to achievement learn with coefficient of regresi 0.03 ( test of t 0.064 ) so that can be concluded that there are influence betwee motivation, interest and emotional intellegence to achievement learn with value of $\mathrm{R} 2=0.696$ and $\mathrm{F}$ Value $=93.800$ significant $=0.000<$ its 0.05 meaning equal to $69.6 \%$ achievement variation of learn to be explained by motivation variable, emotional intellegence and interest, the rest $30.4 \%$ determined by other factor and by simultan motivation variable, emotional intellegence and enthusiasm can explain achievement learn student. Conclusion According to research, there is significant betwenit the influence of motivation, interest and emotional intellegence to achievement learn.It is suggested to educator to increase ability teach it and risk motivation, interest and emotional intellegence and suggested for futher research on exploring physic and Phisicologist factor related/influence the achievement learn student.

Key word : Motivation, Interest, Emotional Intellegence and Achievement Learn.

\section{Pendahuluan}

Belajar merupakan unsur yang sangat fundamental dalam penyelenggaraan setiap jenis dan jenjang pendidikan. Pencapaian tujuan pendidikan tergantung pada proses belajar yang dialami mahasiswa. Dalam belajar terjadi proses interaksi pikiran, perasaan dan gerakan sehingga terjadi perubahan tingkah laku (Uno, 2008:11). Dalam hubungannya dengan proses interaksi belajar mengajar lebih menekankan pada motivasi belajar. Motivasi belajar yang berasal dari dalam akan memberi dorongan mencapai prestasi dan dorongan memiliki pengetahuan dan ketrampilan untuk masa depan juga memberi pengaruh kuat dan relatif lebih langgeng dibandingkan dengan dorongan dari orang tua dan guru (Syah , 2005:152).
Dalam proses belajar motivasi mahasiswa tercermin melalui ketekunan yang tidak mudah patah untuk mencapai sukses, meskipun dihadang banyak kesulitan. Beberapa penelitian tentang prestasi belajar mahasiswa menunjukkan motivasi sebagai salah satu faktor internal yang berpengaruh terhadap proses dari hasil belajar mahasiswa. Faktor internal yang lain dalam meningkatkan prestasi belajar yaitu minat dan kecerdasan emosional. Kemampuan dan nilai akademis yang tinggi ditunjang dengan kecerdasan emosi dapat membuka kesuksesan bagi seseorang, baik dalam dunia kerja, pribadi, maupun proses belajar mengajar.

Banyak bukti memperlihatkan bahwa orang yang secara emosi cakap 
mengetahui dan menangani perasaan orang lain dengan efektif memiliki keuntungan dalam setiap bidang kehidupan, entah itu dalam, hubungan asmara, hubungan kerja, pendidikan, ataupun persahabatan. Untuk mengetahui efektifitas siswa dalam kegiatan belajar mengajar, dapat dilihat dari prestasi belajar yang dicapai. Prestasi belajar yang baik atau yang memuaskan dipengaruhi banyak faktor diantaranya dipengaruhi motivasi, kecerdasan emosional dan minat.

Dengan melihat prestasi belajar, kita dapat melihat sejauh mana kemajuan dan keberhasilan yang telah dicapai. Prestasi belajar siswa dipengaruhi oleh berbagai faktor yang berdampak baik bagi perubahan perilaku dan prestasi mahasiswa. Menurut Merson U. Sungalang faktor tersebut adalah kecerdasan, bakat, minat dan perhatian, motif, cara belajar, sekolah, lingkungan keluarga, sekolah, disiplin, masyarakat, lingkungan tetangga, dan aktivitas organisasi ( Tu'u, 2004:78). Berdasarkan pada hal tersebut diatas, penulis tertarik untuk meneliti : Pengaruh Motivasi, Minat dan Kecerdasan Emosional Terhadap Prestasi Belajar Mahasiswa Semester VI di Akademi Keperawatan Dharma Husada Kediri. Tujuan penelitian untuk mengatahui pengaruh antara motivasi, minat dan kecerdasan emosional terhadap prestasi belajar mahasiswa semester VI di Akademi Keperawatan Dharma Husada Kediri..

\section{Metode Penelitian}

Desain penelitian yang digunakan analitik kuantitatif dengan pendekatan cross sectional, dimana peneliti menggali dan mengobservasi pengukuran ke dua variabel dilakukan pada saat yang sama dan sifatnya sesaat. Populasi dalam penelitian ini adalah seluruh mahasiswa semester VI tahun 2012 di Akademi Keperawatan Dharma Husada Kediri. Jumlah populasi dan sample 82 mahasiswa, dengan acessable sampling artinya populasi terjangkau. Tehnik sampling yang digunakan dalam penentuan sampel pada penelitian ini adalah dengan Exhautive sampling artinya sampling secara keseluruhan. Pengolahan ini mencakup tabulasi data dan perhitungan statistik dengan uji statistik Regresi Linier Berganda $\mathrm{Y}=\mathrm{a}+\mathrm{bl} \mathrm{X} 1+$ b2 X2 + b3 X3 + e, (Murti, 2009)

\section{Hasil Penelitian}

1. Distribusi Frekuensi Motivasi belajar Dari 82 responden yang diteliti sebagian besar 59 responden $(71.95 \%)$ mempunyai motivasi belajar cukup, 23 responden $(28.05 \%)$ menunjukkan motivasi tinggi, dan tidak ada responden yang mempunyai motivasi rendah dan sangat rendah. Distribusi motivasi belajar responden yang diteliti dapat dilihat pada tabel di bawah ini:

Tabel 4.3 Distribusi Frekuensi Motivasi mahasiswa semester VI Akper Dharma Husada Kediri Tahun 2012

\begin{tabular}{lcc}
\hline \multicolumn{1}{c}{ Motivasi } & Frekwensi & $\%$ \\
\hline $\begin{array}{l}\text { Tinggi } \\
(91-120)\end{array}$ & 23 & 28.05 \\
$\begin{array}{l}\text { Cukup } \\
(61-90)\end{array}$ & 59 & 71.95 \\
$\begin{array}{l}\text { Rendah } \\
(31-60)\end{array}$ & & \\
$\begin{array}{l}\text { Sangat Rendah } \\
(<30)\end{array}$ & & \\
Total & 82 & 100 \\
\hline
\end{tabular}

Sumber: Data Primer, November 2012

2. Distribusi Frekuensi Minat belajar Dari 82 responden yang diteliti dapat diketahui bahwa sebagian besar menunjukkan 63 responden $(76.83 \%)$ menunjukkan minat belajar cukup, 19 responden $(23.17 \%)$ menunjukkan minat belajar tinggi, dan tidak ada satupun responden mempunyai minat rendah dan sangat rendah. Distribusi minat belajar responden yang diteliti dapat dilihat pada tabel di bawah ini: 
Tabel 4.4 Distribusi Frekuensi Minat belajar mahasiswa semester VI Akper Dharma Husada Kediri Tahun 2012

\begin{tabular}{lcc}
\hline \multicolumn{1}{c}{ Minat } & Frekwensi & $\%$ \\
\hline $\begin{array}{l}\text { Tinggi } \\
(91-120)\end{array}$ & 19 & 23.17 \\
$\begin{array}{l}\text { Cukup } \\
(61-90)\end{array}$ & 63 & 76.83 \\
Rendah & & \\
$(31-60)$ & & \\
Sangat & & \\
Rendah & $<$ & \\
30) & & \\
Total & 82 & 100 \\
\hline
\end{tabular}

Sumber: Data Primer, November 2012

3. Distribusi Frekuensi Kecerdasan emosional

Dari 82 responden yang diteliti dapat diketahui bahwa sebagian besar menunjukkan 70 responden $(85.37 \%)$ menunjukkan kecerdasan emosional cukup, sedangkan 11 orang $(13.41 \%)$ menunjukkan tinggi dan 1 orang $(1,22 \%)$ mempunyai kecerdasan emosional rendah. Distribusi Kecerdasan emosional responden yang diteliti dapat dilihat pada tabel di bawah ini:

Tabel 4.5 Distribusi Frekuensi Kecerdasan emosional mahasiswa semester VI Akper Dharma Husada Kediri Tahun 2012

\begin{tabular}{lcc}
\hline \multicolumn{1}{c}{$\begin{array}{c}\text { Kecerdasan } \\
\text { Emosional }\end{array}$} & Frekwensi & $\%$ \\
\hline $\begin{array}{l}\text { Tinggi } \\
(121-160)\end{array}$ & 11 & 13.41 \\
$\begin{array}{l}\text { Cukup } \\
(81-120)\end{array}$ & 70 & 85.37 \\
$\begin{array}{l}\text { Rendah } \\
(41-80)\end{array}$ & 1 & 1.22 \\
$\begin{array}{l}\text { Sangat Rendah } \\
(<40)\end{array}$ & & \\
Total & 82 & 100 \\
\hline
\end{tabular}

Sumber: Data Primer, November 2012

4. Distribusi Frekuensi Prestasi

Kumulatif Mahasiswa

Dari 82 responden yang diteliti dapat diketahui bahwa sebagian besar menunjukkan bahwa $49 \quad(59.76 \%)$ responden mempunyai indeks prestasi baik, $33(40.24 \%)$ responden mempunyai indeks prestasi cukup, dan tidak ada seorangpun responden yang mempunyai indeks prestasi sangat baik dan kurang baik. Distribusi Prestasi Kumulatif responden yang diteliti dapat dilihat pada tabel di bawah ini:

Tabel 4.6 Distribusi Frekuensi Prestasi belajar mahasiswa semester VI Akper Dharma Husada Kediri Tahun 2012

\begin{tabular}{lcc}
\hline Prestasi Belajar & Frekwensi & $\%$ \\
\hline $\begin{array}{l}\text { Sangat Baik } \\
(79-100)\end{array}$ & 0 & 0 \\
$\begin{array}{l}\text { Baik } \\
(68-78)\end{array}$ & 49 & 59.76 \\
$\begin{array}{l}\text { Cukup } \\
(56-67)\end{array}$ & 33 & 40.24 \\
$\begin{array}{l}\text { Kurang Baik } \\
(41-55)\end{array}$ & & \\
Total & 82 & 100 \\
\hline
\end{tabular}

Sumber: Data Primer, November 2012

\section{Hasil penelitian}

Tabel 4.7. Pengolahan data variabel penelitian mahasiswa semester VI Akper Dharma Husada Kediri Tahun 2012

\begin{tabular}{lccccc}
\hline \multicolumn{1}{c}{ Variabel } & $\mathrm{N}$ & Mean & SD & Minimal & Maksimal \\
\hline $\begin{array}{l}\text { IP ( Prestasi } \\
\text { Belajar) }\end{array}$ & 82 & 2.79 & 0.27 & 2 & 3 \\
$\begin{array}{l}\text { Motivasi } \\
\text { Belajar }\end{array}$ & 82 & 87.90 & 8.15 & 71 & 110 \\
$\begin{array}{l}\text { Minat Belajar } \\
\text { Kecerdasan }\end{array}$ & 82 & 86.23 & 6.59 & 68 & 102 \\
Emosional & 82 & 104.94 & 12.18 & 75 & 127 \\
\hline
\end{tabular}

Sumber: Data Primer, November 2012

Berdasarkan tabel 4.7 dapat dijelaskan bahwa Mean (rata-rata) indeks prestasi semester VI sebesar 2.79, dengan nilai maksimal 3.00 , nilai minimal 2.00 dan standar deviasi 0.275. Untuk mean motivasi belajar sebesar 87.90 dengan nilai maksimal 110, nilai minimal 71 dan standar deviasi 8.15. Skor mean minat belajar sebesar 86,23 dengan nilai maksimal 102, nilai minimal 68 dan standar deviasi 6.59. Adapun skor mean kecerdasan emosional sebesar 104,94 
dengan nilai maksimal 127 , nilai minimal 75 dan standar deviasi 12,18.

\section{Analisis Regresi Linear Berganda}

Analisis regresi linear berganda digunakan untuk mengetahui pengaruh secara simultan variabel motivasi, minat dan kecerdasan emosional terhadap prestasi belajar.

Tabel 4.8. Hasil Analisis Regresi Linier Ganda tentang Pengaruh Motivasi dan Kecerdasan Emosional terhadap Prestasi Belajar

\begin{tabular}{lcccc}
\hline $\begin{array}{c}\text { Variabel } \\
\text { Independent }\end{array}$ & $\begin{array}{c}\text { Koefisien } \\
\text { Regresi } \\
\text { (b) }\end{array}$ & $\begin{array}{c}\text { Taraf } \\
\text { Signifikan } \\
(\mathrm{p})\end{array}$ & \multicolumn{2}{c}{$\begin{array}{c}\text { Confidence } \\
\text { Interval }(\mathrm{CI} \\
\text { 95\%) }\end{array}$} \\
\cline { 4 - 5 } & & & $\begin{array}{c}\text { Batas } \\
\text { Bawah }\end{array}$ & $\begin{array}{c}\text { Batas } \\
\text { Atas }\end{array}$ \\
\hline Konstanta & 0.33 & 0.074 & -0.03 & 0.69 \\
Motivasi & 0.02 & $<0.001$ & 0.01 & 0.02 \\
Minat & 0.00 & $<0.001$ & -0.01 & 0.00 \\
Kecerdasan & 0.01 & $<0.001$ & 0.01 & 0.01 \\
emosional & & & & \\
\hline $\begin{array}{l}\text { N observasi }=82 \text { Subjek } \\
\text { Adjusted } R^{2}=69,6 \%\end{array}$ & & & \\
$\mathrm{p}=<0,001$ & & & & \\
\hline
\end{tabular}

Sumber: Data Primer, November 2012

Tabel 4.8 menunjukan terdapat pengaruh motivasi belajar terhadap prestasi belajar pada mahasiswa semester VI yang secara statistik signifikan. Setiap peningkatan skor motivasi sebesar 1 poin meningkatkan nilai prestasi belajar sebesar 0,02 poin $(b=0,02$, CI $95 \%, 0.01$ hingga 0.02).

Tabel 4.8 juga menunjukkan terdapat pengaruh kecerdasan emosional terhadap prestasi belajar pada mahasiswa semester VI yang secara statistik signifikan. Setiap peningkatan skor kecerdasan emosional sebesar 1 poin meningkatkan nilai prestasi belajar sebesar 0,01 poin $(b=0,01$, CI 95 $\%, 0.01$ hingga 0.01). Pada variabel lain juga ditemukan secara statistik tidak ada pengaruh yang sangat signifikan untuk mempengaruhi konstanta terhadap minat belajar. Hal ini dapat dilihat dari parameter pada nilai koefisien konstanta. ( $b=0.33)$. Hal ini dapat dilihat dalam Regresi Linear Berganda yang tidak tercantum variabel minat belajar.

Pada variabel lain juga ditemukan secara statistic tidak ada pengaruh yang signifikan untuk mempengaruhi konstanta terhadap prestasi belajar. Hal ini dapat dilihat dari parameter pada nilai koefisien tersebut ada yang negative. $(b=0.33$; $C I$ 95\%; -0.03 hingga 0.69).

Uji statistik yang digunakan untuk mengetahui pengaruh motivasi, minat belajar dan kecerdasan emosional terhadap prestasi belajar semeseter VI adalah dengan menggunakan Uji Regresi Linear Berganda perhitungan statistik menggunakan bantuan SPSS versi 17 . Berdasarkan perhitungan menggunakan uji regresi linear berganda perhitungan statistik menggunakan bantuan SPSS 17 diperoleh hasil $\mathrm{F}$ hitung $62.22 \mathrm{p}<0.05$, $\mathrm{R}=0.839, \mathrm{R}^{2}=69.6 \%$.

\section{Pembahasan}

1. Pengaruh Motivasi Terhadap Prestasi Belajar

Motivasi adalah perubahan energi dalam diri seseorang yang ditandai dengan timbulnya perasaan dan reaksi untuk mencapai tujuan (Hamalik, 2008:158). Dalam kegiatan belajar, motivasi dapat dikatakan sebagai keseluruhan daya penggerak di dalam diri siswa yang menimbulkan, menjamin kelangsungan dan memberikan arah kegiatan belajar, sehingga diharapkan tujuan dapat tercapai. Dalam kegiatan belajar, motivasi sangat diperlukan, sebab seseorang yang tidak mempunyai motivasi dalam belajar, tidak akan mungkin melakukan aktivitas belajar (Uno, 2009).

Berdasarkan hasil uji statistik variabel motivasi terhadap prestasi belajar diperoleh nilai koefisien regresi sebesar 0,02 , artinya setiap peningkatan 1 poin motivasi belajar akan meningkatkan prestasi belajar sebesar 0.02 poin $(b=$ 0,02, CI 950.01 hingga 0.02). Uji statistik crosstabs tentang pengaruh motivasi terhadap prestasi belajar yaitu bahwa mahasiswa yang mempunyai 
motivasi tinggi dengan prestasi belajar baik berjumlah 22 mahasiswa (91.7\%), sedangkan mahasiswa yang mempunyai motivasi tinggi dengan prestasi belajar cukup berjumlah 2 mahasiswa (8.3\%). Mahasiswa yang mempunyai motivasi cukup dengan prestasi belajar baik berjumlah 25 mahasiswa (43.1\%), sedangkan mahasiswa yang mempunyai motivasi cukup dengan prestasi belajar cukup berjumlah 33 mahasiswa $(56.9 \%)$. Adapun skor untuk menghitung motivasi dilakukan dengan kategori : < 30 nilai sangat rendah, skor $31-60$ nilai rendah, skor 61 - 90 nilai cukap dan 91 - 120 nilai tinggi. Dari hasil penelitian juga mean untuk motivasi sebesar 87.90.

Dari hasil ini dapat dijelaskan adanya pengaruh motivasi terhadap prestasi belajar. Motivasi memberikan dorongan pada individu/mahasiswa untuk melakukan kegiatan belajar. Motivasi berfungsi sebagai pendorong usaha dan pencapaian prestasi, karena secara konseptual motivasi berkaitan dengan prestasi dan hasil belajar. Adanya motivasi yang baik dalam belajar akan menunjukkan hasil yang baik. Dengan kata lain, adanya usaha yang tekun dan terutama didasari adanya motivasi, maka seseorang yang belajar itu dapat melahirkan prestasi yang baik. Intensitas motivasi seseorang siswa akan sangat menentukan tingkat pencapaian prestasi belajarnya. Hasil Penelitian ini sesuai dengan penelitian yang dilakukan oleh Winarno (2008) dengan judul Pengaruh minat, lingkungan dan motivasi belajar dengan prestasi belajar siswa di SMAN 8 Balikpapan. Hasil penelitian menunjukkan bahwa ada pengaruh positif yang signifikan minat belajar terhadap prestasi belajar. Untuk motivasi terhadap prestasi belajar ada pengaruh positif dan signifikan $0,000<$ tingkat alpha 0,05 . Jadi ada pengaruh positif yang signifikan minat, lingkungan dan motivasi belajar secara bersama-sama terhadap prestasi belajar.

Menurut Hamalik (2009) bahwa motivasi merupakan dorongan pada seseorang untuk bertindak atau berperilaku tertentu. Motivasi membuat seseorang memulai, melaksanakan dan mempertahankan kegiatan tertentu. Motivasi mempunyai pengaruh yang besar terhadap tercapainya suatu tujuan. Fungsi dari motivasi adalah mendorong timbulnya suatu perbuatan mengarah dan penggerak kegiatan untuk mencapai suatu tujuan. Secara umum motivasi untuk belajar dapat dikelompokkan dalam dua bentuk yaitu motivasi intrinsik dan motivasi ekstrinsik. Motivasi intrinsik adalah motivasi yang timbul dalam diri seseorang (individu) itu sendiri tanpa adanya paksaan atau dorongan dari luar, namun semata-mata muncul atau kebutuhan dan kesadaran diri untuk melakukan sesuatu atau adanya keinginan untuk mencapai tujuan tertentu. Adapun motivasi ekstrinsik timbul sebagai akibat pengaruh dari luar individu, baik karena ajakan, suruhan atau paksaan dari orang lain atau kondisi lingkungan sedemikian rupa sehingga seseorang melakukan sesuatu untuk mencapai tujuan.

Menurut Uno (2009:5) dapat disimpulkan bahwa motivasi merupakan kekuatan yang mendorong seseorang melakukan sesuatu untuk mencapai tujuan, Kekuatan motivasi sebaiknya dirangsang agar tumbuh dalam dirinya untuk mencapai harapan atau tujuan dalam belajar sehingga mahasiswa dapat mencapai prestasi yang dicita-citakan.

Dalam kegiatan belajar-mengajar, peran motivasi baik motivasi intrinsik maupun motivasi ekstrinsik sangat diperlukan. Dengan motivasi, mahasiswa dapat mengembangkan aktifitas dan inisiatif, dapat mengarahkan dan memelihara ketekunan dalam melakukan kegiatan belajar. Pemberian motivasi yang sering dilakukan di kelas atau di lahan praktek oleh dosen atau sesama mahasiswa juga akan menambah kuatnya untuk meningkatkan belajarnya sehingga prestasi bertambah baik.

Pemberian motivasi atau menumbuhkan motivasi perlu dilakukan 
saat diterima menjadi mahasiswa dan memberikan prospek atau memantapkan cita-citanya untuk menjadi perawat. Tentunya kalau mahasiswa ingin menjadi perawat maka mahasiswa termotivasi untuk menyelesaikan tugas akademiknya tepat waktu dan mendapatkan beasiswa dari institusi. Pemberian beasiswa ini diharapkan akan menambah motivasi belajar mahasiswa sehingga prestasi meningkat. Hal ini sesuai pendapat Sardiman (2006) bahwa cara untuk menumbuhkan motivasi dalam kegiatan belajar di sekolah diantaranya dengan memberi pujian, hadiah dan angka.

Banyak faktor yang berhubungan dengan motivasi belajar anak. Bisa berasal dari anak itu sendiri, guru, orang tua, sekolah, atau teman-temannya. Bila anak mengalami penurunan prestasi belajar akibat menurunnya motivasi, maka orang tua perlu segera memperhatikan dan mencari penyebab penurunan prestasi belajarnya. Dapat disimpulkan bahwa ada pengaruh positif dan signifikan antara motivasi belajar terhadap prestasi belajar.

\section{Pengaruh Minat Terhadap Prestasi Belajar}

Minat belajar adalah suatu keadaan dimana siswa merasa senang dan memberi perhatian pada mata pelajaran serta kemauan dalam belajar yang menimbulkan sikap keterlibatan setiap orang yang ingin belajar. Bilamana siswa memiliki minat yang tinggi untuk belajar, maka ia akan berupaya mempersiapkan hal-hal yang berkaitan dengan apa yang akan dipelajar secara lebih baik sehingga akan berkaitan dengan evaluasi hasil belajar (Aunurrahman,2010: 178)

Dari hasil penelitian diperoleh nilai koefisien regresi sebesar 0,00 , artinya tidak ada pengaruh yang signifikan $(b=$ 0,00, CI 95 -0.01 hingga 0.00),

tetapi diuji linearitas pada gambar 4.2 menunjukan terdapat pengaruh positif antara motivasi belajar terhadap prestasi belajar mahasiswa $\left(\mathrm{R}^{2}=0.42\right)$. Adapun skor untuk menghitung minat dilakukan dengan kategori : < 30 nilai sangat rendah, skor $31-60$ nilai rendah, skor $61-90$ nilai cukap dan 91 - 120 nilai tinggi. Dari hasil penelitian juga mean untuk minat sebesar 86.23.

Hal di atas disebabkan banyak faktor yang mempengaruhi minat terhadap prestasi belajar, diantaranya ada nya kurangnya sosialisasi tentang ilmu keperawatan atau kurangnya penjelasan tentang kalender akademik. Hal inilah menjadikan kejenuhan dan kebosanan dari mahasiswa tentang pencapaian kompetensi di setiap mata kuliah, penyelesaian tugas di dalam menjalankan praktek klinik keperawatan atau kurangnya ketertarikan untuk menyelesaikan tugas. Selain itu kurangnya pemberian stimulus dari dosen, keluarga dan teman sehingga dapat mengendorkan/menurunkan minat dalam mencapai prestasi belajar.

Menurut Tanner \& Tanner (Slameto, 2009) minat dapat dibentuk dengan jalan memberikan informasi-informasi mengenai subyek yang menjadi pilihannya. Minat belajar di pendidikan keperawatan dapat ditingkatkan dengan memberikan tentang keperawatan yang meliputi apa itu perawat, peran dan fungsi perawat, bagaiman prosedur untuk menjadi perawat, prasarat apa yang harus dimiliki dan sebagainya. Dapat pula untuk membangkitkan minat dengan cara memberikan insentif.

Menurut Sardiman (2007) cara untuk membankitkan minat dilakukan dengan membangkitkan adanya suatu kebutuhan, menghubungkan dengan persoalan pengalaman yang lampau, memberi kesempatan untuk mendapatkan hasil yang baik, dan menggunakan berbagai macam bentuk mengajar. Minat belajar timbul karena rangsangan dari dalam dan dari luar. Dalam diri manusia jika dorongan dieksplorasi dan dimanipulasi terhadap dunia luar, maka lama kelamaan timbullah minat terhadap sesuatu. Sehingga minat seseorang mendorongnya 
untuk berbuat lebih giat dan baik. Minat akan mendorong mahasiswa untuk belajar lebih baik daripada belajar tanpa minat. Minat akan timbul apabila mahasiswa tertarik akan sesuatu yang akan dipelajari dirasakan bermakna bagi dirinya. (Hamalik, 2009)

Adanya pandangan yang negatif terhadap materi kuliah, penugasan dan teknik ujian yang dianggap sulit menyebabkan mahasiswa akan pesimis. Kondisi ini akhirnya menyebabkan mahasiswa menurunkan minat sehingga prestasi belajar menurun. Minat besar pengaruhnya terhadap belajar. Bahan pelajaran yang menarik minat siswa akan lebih mudah dipelajari dan menambah minatnya dalam kegiatan belajar.

Guru yang berhasil membina kesediaan belajar siswa berarti telah melaksanakan hal yang penting demi keberhasilan siswa-siswanya. Anak yang berminat terhadap kegiatan belajar akan berusaha lebih keras untuk belajar dibandingkan dengan anak yang kurang berminat. Bahan pelajaran yang menarik minat siswa, lebih mudah dipelajari sehingga minat dapat meningkatkan hasil belajar. Membangkitkan minat terhadap sesuatu pada dasarnya adalah membantu siswa melihat bagaimana hubungan antara materi yang diharapkan untuk dipelajari dengan diri sendiri sebagai individu. Minat merupakan salah satu kunci utama untuk memperlancar, menggairahkan dan meningkatkan hasil belajar mhasiswa.

Minat merupakan kecenderungan yang relatif tetap untuk lebih memperhatikan dan mengingat secara terus menerus yang diikuti rasa bangga, senang serta memperoleh suatu kepuasan dalam mencapai tujuan pembelajaran. Tercapainya tujuan pembelajaran ditandai dengan hasil belajar yang diperoleh meningkat. Siswa memiliki minat yang tinggi untuk belajar, maka ia akan berupaya mempersiapkan hal-hal yang berkaitan dengan apa yang akan dipelajari secara lebih baik sehingga prestasi belajar akan bertambah/meningkat (Aunurrahman ,2010: 178).

Agar minat belajar dapat bertambah baik diharapkan perlunya dosen seyogyanya memberi evaluasi tentang atau stimulus untuk membangkitkan minat mahasiswa dengan berbagai cara. Hal ini sesuai pendapat Slameto (2009) yaitu dalam mengukur minat belajar siswa dilakukan dengan menambah kemauan untuk belajar, meningkatkan kesungguhan belajar mahasiswa, meningkatkan ketekunan dan kerajinan dalam belajar.

3. Pengaruh Kecerdasan Emosional Terhadap Prestasi Belajar

Kecerdasan emosional adalah teknik berhubungan dengan manusia seperti menaruh minat kepada orang lain, menyebut dan mengingat nama orang supaya orang lain senang, memberi penghargaan, memberi pujian, mendengarkan orang lain ketika orang lain berbicara, selalu berempati, tersenyum, proaktif.

Berdasarkan hasil uji statistik variabel kecerdasan emosional terhadap prestasi belajar diperoleh nilai koefisien regresi sebesar 0,01 , artinya setiap peningkatan 1 poin motivasi belajar akan meningkatkan prestasi belajar sebesar 0.01 poin $(b=$ 0.02, CI 950.01 hingga 0.01). Dan Gambar 4.3 menunjukan terdapat pengaruh positif antara kecerdasan emosional terhadap prestasi belajar mahasiswa $\left(\mathrm{R}^{2}=0.57\right)$. Adapun skor untuk menghitung minat dilakukan dengan kategori : < 40 nilai sangat rendah, skor $41-80$ nilai rendah, skor $80-120$ nilai cukap dan 121 - 160 nilai tinggi. Dari hasil penelitian mean untuk kecerdasan emosional sebesar 104.94. Uji statistik dengan hasil Crosstabs tentang pengaruh kecerdasan emosional terhadap prestasi belajar yaitu bahwa mahasiswa yang mempunyai kecerdasan emosional tinggi dengan prestasi belajar baik berjumlah 11 mahasiswa (100\%), sedangkan mahasiswa yang mempunyai kecerdasan emosional cukup dengan prestasi belajar baik 
berjumlah 36 mahasiswa (51.4\%). Mahasiswa yang mempunyai kecerdasan emosi cukup dengan prestasi belajar cukup berjumlah 34 mahasiswa (48.6\%), sedangkan mahasiswa yang mempunyai kecerdasan emosi cukup dengan prestasi belajar cukup berjumlah 31 mahasiswa $(50.8 \%)$.

Kecerdasan emosional membantu meningkatkan intelektual mahasiswa yang pada akhirnya akan meningkatkan prestasi mahasiswa. Hal ini sesuai pendapat Peter Solvey dan Jack Mayer yang dikutif Aunurrohman( 2010) bahwa kecerdasan emosional adalah kemampuan untuk mengenali perasaan untuk meraih dan membangkitkan pikiran, memahami perasaan dan maknanya serta mengendalikan perasaan secara mendalam sehingga membantu perkembangan emosi dan intelektual.

Salah satu faktor yang mempengaruhi prestasi belajar siswa adalah intelegensi/kecerdasan : baik kecerdasan intelektual, emosional dan spiritual. Semakin tinggi tingkat kecerdasan emosional mahasiswa maka semakin tinggi pula prestasi belajar dan demikian pula sebaliknya. Kecerdasan emosional adalah kemampuan seseorang mengatur kehidupan emosinya dengan inteligensi (to manage our emotional life with intelligence) menjaga keselarasan emosi dan pengungkapannya (the appropriateness of emotion and its expression) melalui keterampilan kesadaran diri, pengendalian diri, motivasi diri, empati dan keterampilan social.

Seorang mahasiswa dengan tingkat kecerdasan emosional tinggi akan mampu memotivasi dirinya untuk lebih berprestasi, mampu mengendalikan diri serta menahan gejolak yang dapat menghambat keberhasilannya dalam meraih prestasi belajarnya yang lebih baik, selain itu dengan kecerdasan emosi akan membuat seseorang lebih tenang dalam menghadapi berbagai permasalahan sehingga akan membantu dalam meraih prestasi belajarnya yang tinggi pula.
Substansi dari kecerdasan emosional adalah kemampuan merasakan dan memahami untuk kemudian disikapi secara manusiawi. Orang yang EQ-nya baik, dapat memahami perasaan orang lain, dapat membaca yang tersurat dan yang tersirat, dapat menangkap bahasa verbal dan non verbal. Semua pemahaman tersebut akan menuntunnya agar bersikap sesuai dengan kebutuhan dan tuntutan lingkungannya..

Pusat dari EQ adalah hati. Hati mengaktifkan nilai-nilai yang paling dalam, mengubah sesuatu yang dipikirkan menjadi sesuatu yang dijalani. Hati dapat mengetahui hal-hal yang tidak dapat diketahui oleh otak, hati adalah sumber keberanian dan semangat, integritas dan komitmen. Hati merupakan sumber energi dan perasaan terdalam yang memberi dorongan untuk belajar, menciptakan kerja sama, memimpin dan melayani.

Proses pembelajaran dimana seorang mahasiswa dituntut untuk mampu memenuhi banyak sekali kompetensi yang tertuang dalam mata kuliah - mata kuliah, interaksi banyak dosen dan mahasiswa yang lain. Dalam mencapai kompetensi tersebut mahasiswa harus berinteraksi dengan beberapa matakuliah, dosen dan teman yang tidak disukai. Disamping mahasiswa harus bekerja secara individu, sering kali mahasiswa juga harus kerja secara berkelompok. Situasi tersebut dibutuhkan kecerdasan emosional yang baik bagi seorang mahasiswa agar mampu memahami dan mengelola dirinya sendiri dan lingkungan. Dengan kecerdasan emosional ini diharapkan mahasiswa mampu merespon/berperilaku yang tepat sesuai dengan tuntutan lingkungan.

Prestasi belajar yang baik juga dibutuhkan kecerdasan emosional yang baik pula, dikarenakan prestasi belajar juga mencerminkan kemampuan mahasiswa dalam aspek afektif. Dalam penelitian ini pengaruh kecerdasan emosional terhadap prestasi belajar mahasiswa dalam kategori sangat kuat, hal tersebut disebabkan didalam proses 
pembelajaran seorang dosen juga sering kali memberikan pembelajaran bersifat kelompokk seperti (laboratoirum, diskusi/seminar, role play, praktek klinik.) yang nantinya dijadikan dasar evaluasi/penilaian.

4. Pengaruh Antara Motivasi, Minat Belajar dan Kecerdasan Emosional Secara Bersama - Sama Terhadap Prestasi Belajar Mahasiswa

Motivasi dan kecerdasan emosional berhubungan positif dan signifikan terhadap prestasi belajar. Secara bersamasama motivasi dan kecerdasan emosional mampu mempengaruhi prestasi belajar.

Berdasarkan perhitungan statistik menunjukkan nilai R2 sebesar 0.696, Koefisien korelasi berganda $(\mathrm{R})=0.84$ dan nilai $\mathrm{F}=93.300$, makna $\mathrm{R} 2=0.696$ adalah sebesar $69.6 \%$ prestasi belajar mahasiswa dijelaskan oleh variabel motivasi, minat belajar dan kecerdasan emosional, sisanya $30.4 \%$ ditentukan oleh faktor lain yaitu faktor fisik (kondisi umum jasmani), sikap, bakat. Faktor lingkungan sosial dan lingkungan nonsosial, seperti sarana dan prasarana sekolah/ belajar, letaknya rumah tempat tinggal keluarga, keadaan cuaca dan waktu belajar yang digunakan anak dan faktor pendekatan belajar.

Dari pengujian regresi linear ganda didapatkan variabel minat tidak signifikan. Hal ini disebabkan kurangngnya minat belajar mahasiswa terhadap mata kuliah di bidang keperawatan. Sesuatu yang menarik minat tidak menyenangkan maka hasilnya mempengaruhi prestasi belajar. Dapat disimpulkan terdapat pengaruh positif yang signifikan antara variabel motivasi dan kecerdasan emosional secara bersama-sama terhadap prestasi belajar mahasiswa. Hipotesis yang menyatakan bahwa ada pengaruh motivasi dan kecerdasan emosional mahasiswa terhadap prestasi belajar telah terbukti kebenarannya, yang paling besar pengaruhnya adalah motivasi belajar kemudian kecerdasan emosional. Adapun untuk minat ada hubungan tetapi tidak signifikan.

Sebenarnya dari faktor psikologis yang mempengaruhi prestasi belajar diantaranya bakat, sikap, minat, motivasi dan intelegensi. Sehingga faktor psikologis harus dikembangkan dan dimengerti dan diamalkan oleh semua mahasiswa. Adanya pandangan yang negatif terhadap materi kuliah yang dianggap sulit, penugasan yang menyulitkan serta teknik ujian yang dianggap sulit akan menyebabkan individu (mahasiswa) akan pesimis, kondisi ini akhirnya menyebabkan seorang pelajar (mahasiswa) akan memiliki minat yang rendah sehingga mempengaruhi prestasi belajar yang rendah. Prestasi belajar mahasiswa yang rendah juga disebabkan oleh salah satu faktor yang terkait, yakni kinerja dosen dalam pembelajaran turut memegang kendali atas keberhasilan dalam proses belajar mahasiswa.

\section{Kesimpulan}

1. Ada pengaruh motivasi terhadap prestasi belajar mahasiswa semester VI Akper Dharma Husada Kediri.

2. Tidak ada pengaruh minat belajar terhadap prestasi belajar mahasiswa semester VI Akper Dharma Husada Kediri. Sedangkan secara substantif tidak signifikan minat belajar dengan prestasi belajar dikarenakan perbedaannya sangat kecil.

3. Ada pengaruh kecerdasan emosional terhadap prestasi belajar mahasiswa semester VI Akper Dharma Husada Kediri

4. Secara bersama-sama ada pengaruh motivasi dan kecerdasan emosional terhadap prestasi belajar mahasiswa semester VI Akper Dharma Husada Kediri.

\section{Saran}

1. Bagi Mahasiswa

a. Mahasiswa hendaknya lebih memacu minat, motivasi dan 
kecerdasan emosionalnya agar dapat mengikuti semua mata kuliah dan praktek keperawatan dengan harapan hasil prestasi akademik menjadi lebih baik.

b. Hendaknya mahasiswa menumbuhkan minat belajar dengan meningkatkan perasaan senang dan perhatian dalam belajar, serta menyadari adanya manfaat dan fungsi dari perkuliahan untuk dapat meningkatkan prestasi belajarnya.

c. Diharapkan mahasiswa menyadari pentingnya memiliki kecerdasan emosional yang tinggi dengan jalan pandai mengendalikan amarah, sabar menghadapi ujian, suka menolong, tidak mudah putus asa dan memiliki motivasi dan minat yang tinggi dalam berprestasi

2. Bagi Institusi Pendidikan

Diharapkan memberikan atau mengadakan pelatihan training motivasi atau pengembangan soft skill bagi dosen dan mahasiswa sehingga menumbuhkan kinerja dosen dan mahasiswa dapat meningkatkan prestasi belajar yang optimal.

3. Bagi Dosen

Diharapkan para dosen harus meningkatkan kemampuan mengajarnya yaitu dalam hal penguasaan materi pembelajaran, penggunaan media pembelajaran, membangkitkan motivasi dan minat mahasiswa serta memberian penghargaan atau reward sehingga mahasiswa dapat meningkatkan prestasi belajar yang optimal.

\section{Daftar Pustaka}

Aunurrahman, 2010, Psikologi Belajar, Jakarta, Rineka Cipta

Hamalik Uno. 2008. Proses Belajar Mengajar. Jakarta: PT.Bumi Aksara.

Murti B, 2009.Desain dan Ukuran Sampel Untuk Penelitian Kuantitatif dan Kualitatif di Bidang Kesehatan. Yogyakarta:Gadjah Mada University Press.

Riwidikdo H. 2008. Statistik Kesehatan. Yogyakarta: Mitra Cendekia Pres.

Syah M, 2005, Psikologi Belajar, Jakarta, PT. Raja Grafindo Persada,

Sardiman A M. 2006. Interaksi dan Motivasi Belajar Mengajar. Jakarta: Raja Grafindo Persada.

Slameto.2009. Belajar dan Faktor-faktor Yang Mempengaruhi. Jakarta:PT.Rineka Cipta.

Sunaryo. 2004. Psikologi Untuk Keperawatan. Jakarta: EGC

Tu'u T.2004. Peran Disiplin Pada Perilaku dan Prestasi Siswa. Jakarta:Rineka Cipta

Uno BH, 2010, Belajar Psikologi, Jakarta, Cetakan Kedua. Jakarta: Bumi Antariksa

Uno BH, 2008. Orientasi Baru dalam Psikologi Pembelajaran. Cetakan Kedua. Jakarta: Bumi Antariksa

Winarno, 2008, Pengaruh Minat, Lingkungan dan Motivasi Belajar dengan Prestasi Belajar di SMAN 8 Balikpapan, Tesis Magister 